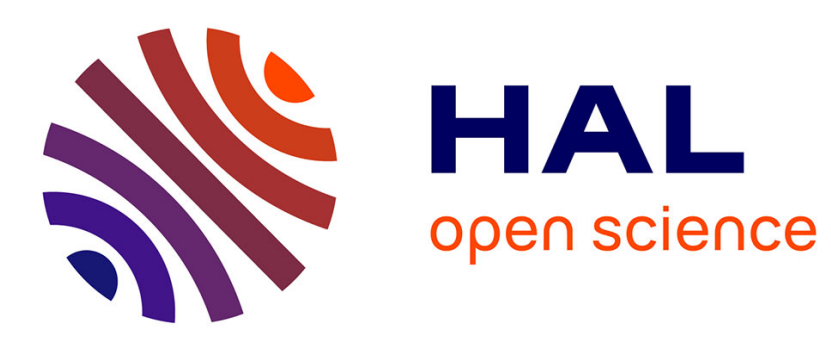

\title{
Consumer Intentions on Social Media: A fsQCA Analysis of Motivations
}

Patrick Mikalef, Ilias O. Pappas, Michail Giannakos

\section{To cite this version:}

Patrick Mikalef, Ilias O. Pappas, Michail Giannakos. Consumer Intentions on Social Media: A fsQCA Analysis of Motivations. 15th Conference on e-Business, e-Services and e-Society (I3E), Sep 2016, Swansea, United Kingdom. pp.371-386, 10.1007/978-3-319-45234-0_34 . hal-01702203

\section{HAL Id: hal-01702203 \\ https://hal.inria.fr/hal-01702203}

Submitted on 6 Feb 2018

HAL is a multi-disciplinary open access archive for the deposit and dissemination of scientific research documents, whether they are published or not. The documents may come from teaching and research institutions in France or abroad, or from public or private research centers.
L'archive ouverte pluridisciplinaire HAL, est destinée au dépôt et à la diffusion de documents scientifiques de niveau recherche, publiés ou non, émanant des établissements d'enseignement et de recherche français ou étrangers, des laboratoires publics ou privés.

\section{(c)(1)}

Distributed under a Creative Commons Attribution| 4.0 International License 


\title{
Consumer Intentions on Social Media: A fsQCA Analysis of Motivations
}

\author{
Patrick Mikalef, Ilias O. Pappas and Michail Giannakos \\ Department of Computer and Information Science, Norwegian University of Science and Tech- \\ nology, Sem Saelandsvei 9, 7491, Trondheim, Norway \\ \{patrick.mikalef, ilpappas, michailg\}@idi.ntnu.no
}

\begin{abstract}
With social media gaining rapidly in popularity, a large number of companies have initiated attempts to capitalize on the large user base present on such platforms. Yet, it still remains unclear how affordances that social media facilitate can influence consumer intentions to purchase and engage in word-ofmouth. This paper builds on the distinction between utilitarian and hedonic features, and empirically examines how these aspects present on social media platforms affect consumer behavior. Using survey data from 165 social media users we perform fuzzy set Qualitative Comparative Analyses (fsQCA) to extract patterns of factors that impact both purchase, and word-of-mouth intentions. The outcomes of the analyses demonstrate that realizing high purchase and word-ofmouth intentions can be achieved through multiple ways which also depend on gender and spending history. Practical and theoretical implications are discussed, particularly concerning how these findings can guide the design of successful social media outlets for commerce.
\end{abstract}

\section{Introduction}

Social media have managed in very short period of time to radically change the way Internet users communicate and interact with each other. With the large user base present today on social media, business executives have been particularly attracted to the potential provided by these platforms to enact their competitive strategies [1]. The diversity of media supported by social media platforms, in combination with the vast user base and the rich profile and navigational information, have elevated the interest particularly for marketing and commerce purposes [2]. Indicative of this trend, the term social commerce has been coined to refer to the various types of commercial activities used on social media in order to enhance customer participation [3] and achieve greater economic value [4]. Within the scope of social commerce activities are marketing new products through interactive campaigns, enabling product browsing and purchasing in social commerce marketplaces, and facilitating interactions between consumers during the search and purchase of products [5].

Despite these very promising prospects for leveraging social media to gain a competitive advantage, a number of studies have revealed that in certain occasions companies have rushed into social media without formulating a clear plan [6]. Due to the

adfa, p. 1, 2011.

(C) Springer-Verlag Berlin Heidelberg 2011 
relative novelty of deploying marketing and commerce strategies on social media, not much is known about how consumers respond to such campaigns and what features activate their behaviour. To date there are only a limited number of studies that empirically examine the concept of social commerce and how features available on social media impact consumer conduct [7]. It has been argued that in order to deploy successful marketing strategies and fully harness the potential of social media, it is necessary to understand how consumers utilize the affordances that such platforms offer. While there have been several studies that examine how the influence of specific motivations on social commerce websites impact consumer behaviour, they fail to examine the synergies that these affordances have and how the different combination of elements trigger specific actions.

Therefore, this research aims to address the question of how affordances present on social media influence consumer conduct. More specifically we seek to understand the mechanisms that promote intentions to purchase and word-of-mouth. To do so, we distinguish characteristics of social media in two major categories, utilitarian and hedonic ones. Analysing data from 165 social media users through the novel data analysis technique fuzzy set Qualitative Comparative Analysis (fsQCA), we aim to identify patterns of characteristics on social media that promote purchase and word-of-mouth proclivity. The statistical technique fsQCA builds on the ideas of complexity theory and is aimed at uncovering patterns of factors that stimulate purchasing and word-of-mouth intentions. In contrast with other statistical methods, it builds on the notion of equifinality, meaning that a specific outcome can be caused by more than one combination of factors. By doing so, we aim to highlight that there are different profiles of consumers and that their actions are triggered by different combinations of social commerce affordances.

In the next section we introduce the theoretical background on online commerce motivations as described under the utilitarian and hedonic motivation lens. In section 3 we present the research propositions to be explored, while in section 4 the data collection method and construct development process are discussed. Section 5 introduces the data preparation and analysis procedure along with results. In section 6 these outcomes are discussed from a theoretical and practical point of view, concluding with section 7 which suggests future directions for research based on the shortcomings of existing studies.

\section{Background}

Research on purchasing and word-of-mouth motivations is not new. The shopping process has been delineated and decomposed in a series of sequential activities, along with the underlying motivations which lead to a purchase decision. Consumers may be motivated to purchase a product due to the potential use it may have to them. On the other hand, it is becoming increasingly apparent that a vast majority of consumers engage in the buying process motivated by their need to socialize, to pass their time, or to discover new trends and fashions [8]. The main premise of these findings are that individuals do not only engage in the shopping process for the utility of the items to be purchased, but 
also for the satisfaction perceived in the process of doing so. As such, two broad categories of motivations have been defined in literature, i.e. utilitarian and hedonic motivations [9]. Utilitarian and hedonic motivation theory attempts to explain why people are inclined to perform a particular behaviour while purchasing. The idea of examining motivations from a utilitarian and hedonic point of view has gained eminence is recent years, with several research studies applying them for both purchasing and word-ofmouth intentions $[10,11,12]$.

The reason for explicitly differentiating between utilitarian and hedonic based motivational factors is that they differ fundamentally. Utilitarian motivations are regarded as rational and goal oriented [13]. Applied to the online shopping context, utilitarian motivations perceive the benefit as stemming from efficiency, completeness, and usability of the process or medium [14]. Contrarily, hedonic motivations are triggered by the search of emotions such as happiness, enjoyment, and adventure experienced during the procedure [15]. In online shopping environments, hedonic motivated consumers are primarily interested in the enjoyment of the process rather than its utility [16]. Hence, hedonic consumers receive satisfaction from the experience itself and from the emotions perceived during it. The combined effect of utilitarian and hedonic motivations was put to test by Babin [10] who argues that hedonic factors influence unplanned shopping whereas utilitarian ones do not. In addition, Jones et al. [11] point out that word-of-mouth is a result of heightened interest in a product, which in turn creates a psychological pressure which is relieved through sharing information. As such, aspects that enabled such hedonic reactions will likely be the cause of word-of-mouth. However, research has also shown that word-of-mouth is associated with cognitive processes, such as perceptions of value and equity evaluations [11].

Although a number of studies have provided insight over the factors that affect consumer behaviour, further exploration of how online shopping mediums stimulate consumer motivations are required. A prominent stream of research has shifted attention towards how motivations are influenced by the design of online mediums [17]. In this direction, the majority of studies have identified utilitarian factors as being the prime motivators of engaging consumers to purchase and word-of-mouth [18, 19]. Some commonly researched utilitarian factors include convenience, information availability, product selection, and customization [20,21]. Despite the dominance of utilitarian design factors in influencing consumer behaviour, research on hedonic factors has also revealed some interesting outcomes. A study by Falk and Campbell [22] argued that when consumers are faced with a storefront or a commercial website of retailer, sensual stimulations and the ability to navigate freely are important. In line with Falk and Campbell's arguments, Eroglu et al. [23] stress that consumers do not navigate through online media solely to gather product-related information and make a rationale decision to purchase products they may need, but also do so to fulfil their needs of experience, emotion, and adventure. As such, similarly to traditional means of shopping, online consumer behaviour is influenced by aesthetics and the overall enjoyment of the experience [24].

The aforementioned studies signal a broadening in perspective with regard to hedonic and utilitarian motivations and aspects present on online media that may trigger 
them. With past studies arguing the impact that these motivations may have on consumer behaviour, and especially purchase and word-of-mouth intentions, it is important to examine their synergistic impact. In particular, in the novel context of social media understanding how affordances present on them affect behaviour is critical in designing marketing strategies.

\section{Research Propositions}

Following the studies described above, researchers in the area of e-commerce have begun to examine how utilitarian and hedonic aspects present on social media influence consumer behaviour [19] [25]. The potential of social media for product and brand marketing has been quickly realized by business executives, with early attempts yielding very promising results [26]. These outcomes have increased the interest of companies to deploy marketing strategies on social media in order to attract new customers and increase revenues. However, the interaction that consumers develop with the affordances present on social media as well as how these interactions impact the behaviour is a subject that remains relatively unexplored. Thus, there is a need to understand what aspects of social media motivate consumers to take action, and how these differ based on their profiles. We argue that there is diversity in the utilitarian and hedonic factors that influence consumer intentions to purchase and word-of-mouth. As such, it is critical to first distinguish between the primary utilitarian and hedonic aspects present on social media websites.

With a vast majority of studies focusing on utilitarian aspects of online shops, several important factors have been identified to date [27]. In the present study we follow the aspects put forth by Wolfinbarger and Gilly [28], who identify between convenience, information availability, and product selection. We also include personal recommendations as an important utilitarian aspect since through the profile developed on social media, consumers are presented with products that are tailored to their likings [16]. These factors are recurring in literature with numerous studies indicating their importance as part of the utilitarian motivation. The selection of the aforementioned factors has been based on their applicability to the social media context, and on past studies signalling the significance in other settings [12].

Concerning hedonic aspects, past studies have put forth a number of different factors such as trend discovery (keeping up with new trends and browsing new products), socializing (ability to socialize with friends and other shoppers), adventure (the stimulation felt during the browsing of products) and authority (the feeling of being able to control the medium in a way that suits the shoppers needs) $[29,30,31]$. As with utilitarian aspects, it is important to distinguish aspects of a hedonic perspective that are applicable on social media. Therefore, a number of hedonic factors that were related only to conventional stores were omitted.

Our research also identifies between profiles of consumers on social media. Gender differences in online shopping behaviour have been noted in several past studies [32, 33]. The differences noted have been traced back to how males and females differ in their perceptions of web technologies and the aspects they focus on or find important 
[34]. Further to gender differences, a significant factor for distinguishing between profiles of online consumers is their purchase history. Consumers that tend to buy frequently and are more likely to spend money online have been found to be influenced by different aspects during their shopping process [35]. The main premise of our research framework is that multiple types of consumers exist, and all have a different combination of factors (utilitarian and hedonic) that influence their shopping behaviour; be it to purchase or word-of mouth. In contrast with past studies, we assume that both purchase intentions and word of mouth intentions are triggered by a multitude of different combinations of affordances. This leads us to the following research propositions:

Proposition 1. There is no single best configuration of consumers' demographics, utilitarian and hedonic motivation aspects that leads to high intention to purchase or word-of-mouth; instead, multiple, equally effective configurations of causal factors exist.

Proposition 2. Single causal motivational values may be present or absent within configurations for consumers' high intention to purchase or word-of-mouth, depending on how they combine with other causal conditions.

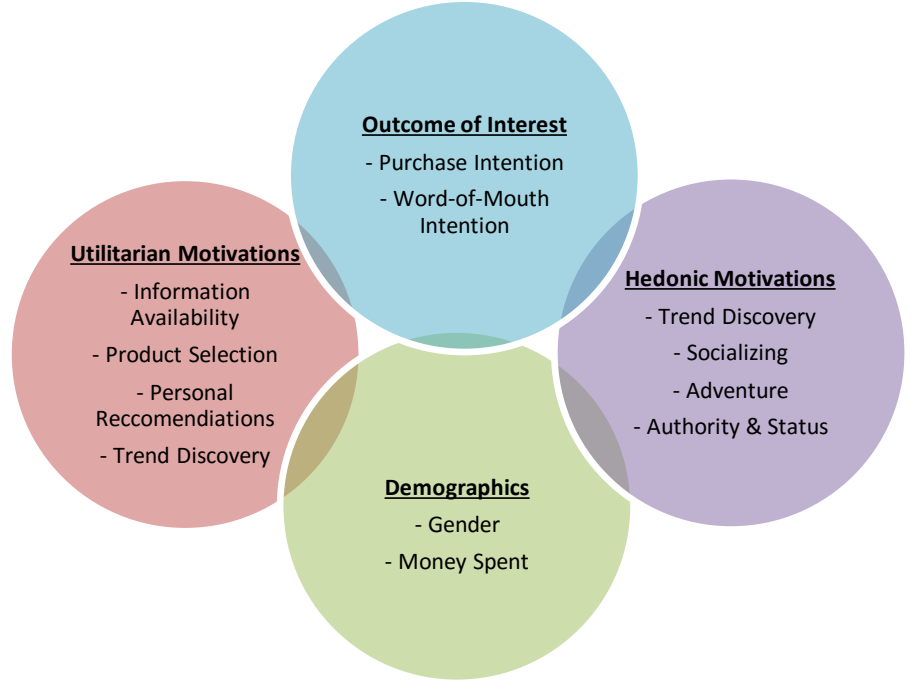

Fig. 1. Factors that affect consumers' intentions to purchase and word-of-mouth on social media 


\section{$4 \quad$ Methodology}

\subsection{Sampling}

In order to explore the research propositions of this study a custom-built survey instrument was developed. The target population for administering the survey were individuals that had prior experience with using social media, and specifically for purposes including product browsing. The questionnaire was divided into three main parts. The first asked respondents to fill out information about their demographics and their habits concerning the use of social media. The second part was targeted in measuring the importance they attribute to utilitarian and hedonic aspects of social media. Finally, the third part was aimed at measuring the intentions of users to purchase and share productrelated information found on social media. To ensure that there was no bias in the sample, multiple sources were used including a mailing list of over 600 respondents of an academic institution, approximately 20 forum boards of difference topics (fashion, computers, hobbies etc.). In total, the questionnaire contained 55 questions divided into the three aforementioned parts. The final number of fully complete responses were 165 which were then used for further analysis.

The descriptive statics of the final sample of respondents are depicted in Table 1 below. In terms of gender, the final sample presents an almost equal distribution between male and female respondents. The largest proportion of responses were from young users, however, this is in coherence with the demographics of social media users [36]. In addition, most respondents were from a relatively high educated background, with experience in online shopping, and a high frequency of using social media.

Table 1. Sample descriptive statistics

\begin{tabular}{llll}
\hline Variable & $\begin{array}{l}\text { Percentage } \\
(\mathbf{N = 1 6 5 )}\end{array}$ & Variable & $\begin{array}{l}\text { Percentage } \\
(\mathbf{N = 1 6 5})\end{array}$ \\
\hline Gender & & Online Expenditure (€/Month) & \\
Male & $56 \%$ & Never purchased online & $6 \%$ \\
Female & $44 \%$ & $1-24 €$ & $44 \%$ \\
Education & & $25-50 €$ & $25 \%$ \\
Primary school & $1 \%$ & $51-100 €$ & $16 \%$ \\
Junior high school & $1 \%$ & $101-250 €$ & $7 \%$ \\
High school & $14 \%$ & $>250 €$ & $2 \%$ \\
University & $56 \%$ & Frequency of social media use & \\
Post-graduate & $28 \%$ & Several times a day & $55 \%$ \\
Age Group & & About once a day & $21 \%$ \\
$<24$ & $50 \%$ & $3-5$ times a week & $8 \%$ \\
$25-34$ & $37 \%$ & $1-2$ times a week & $4 \%$ \\
$35-44$ & $7 \%$ & Every few weeks & $4 \%$ \\
$45-54$ & $6 \%$ & Less often & $7 \%$ \\
$>55$ & $0 \%$ & & \\
\hline
\end{tabular}




\subsection{Measures}

The constructs used in the study included adapted measures of past research studies as well as previously empirical tested ones. Operational definitions as well as key references for construct development are provided in Table 2. All items were measured on a 7-point likert scale in which respondents were asked to evaluate how much they agreed or disagreed with several sentences related to the constructs they were assigned to measure. The full questionnaire along with statistics on the item level are presented in Appendix A.

Table 2. Construct Operational Definitions

\begin{tabular}{|l|l|l|}
\hline Construct & Operational Definition & $\begin{array}{l}\text { Key } \\
\text { References }\end{array}$ \\
\hline Convenience & $\begin{array}{l}\text { The level of convenience perceived when browsing } \\
\text { products or services on social media }\end{array}$ & $\begin{array}{l}{[30],[37,} \\
38]\end{array}$ \\
\hline $\begin{array}{l}\text { Information } \\
\text { Availability }\end{array}$ & $\begin{array}{l}\text { The amount of available information regarding products } \\
\text { or services on social media }\end{array}$ & {$[28],[30]$} \\
\hline Product Selection & The diversity of products or services on social media & {$[28],[30]$} \\
\hline $\begin{array}{l}\text { Personal } \\
\text { Recommendation }\end{array}$ & $\begin{array}{l}\text { The compatibility of customized advertisements pre- } \\
\text { sented to users on social media based on their profiles }\end{array}$ & {$[30],[37]$,} \\
\hline Trend Discovery & $\begin{array}{l}\text { The effectiveness of social media in providing the latest } \\
\text { information about new trends and fashions }\end{array}$ & {$[29,30]$} \\
\hline Socializing & $\begin{array}{l}\text { The level of use of synchronous or asynchronous means } \\
\text { of communication with fellow peers during product or } \\
\text { service browsing on social media }\end{array}$ & {$[28],[30]$} \\
\hline Adventure & $\begin{array}{l}\text { The degree to which social media provide a novel and } \\
\text { interesting browsing experience towards users, and the } \\
\text { sense of excitement perceived during use }\end{array}$ & {$[40]$} \\
\hline $\begin{array}{l}\text { The sense of authority perceived over social media when } \\
\text { Intention }\end{array}$ & $\begin{array}{l}\text { The intention to purchase a product seen on a social me- } \\
\text { dia }\end{array}$ & {$[42,43]$} \\
\hline Purchase Intention & The intention to share information with peers about \\
\hline products or services with peers on social media & {$[43,44]$} \\
\hline
\end{tabular}

\subsection{Reliability and Validity}

Since latent variables were measured through a reflective mode, they were subjected to reliability, convergent and discriminant validity tests. To evaluate reliability, tests were performed at both the construct and item level. At the construct level all Cronbach Alpha $(\mathrm{CA})$ values were above the lower threshold of 0.7 . To determine item-level reliability, construct-to-item loadings were assessed, with all items having loadings greater than 0.7, thus indicating that they are reliable measures of the overall construct. Convergent validity was established by examining if Average Variance Extracted (AVE) scores were above the lower limit of 0.50. As indicated in Table 3, all AVE values exceed the threshold, indicating that convergent validity of constructs is established. Discriminant validity was tested through two ways. The first was by identifying if all 
constructs AVE square root was greater than its highest correlation with any other construct (Fornell-Larcker criterion), while the second was by examining if each indicators outer loadings on its assigned construct was greater than its cross-loadings with any other construct. Confirming reliability, convergent and discriminant validity indicates that the data are valid to use for further analysis.

Table 3. Inter-construct correlations and validity measures

\begin{tabular}{|l|c|c|c|c|c|c|c|c|c|c|}
\hline & $(\mathbf{1})$ & $(\mathbf{2})$ & $\mathbf{( 3 )}$ & $\mathbf{( 4 )}$ & $\mathbf{( 5 )}$ & $\mathbf{( 6 )}$ & $\mathbf{( 7 )}$ & $\mathbf{( 8 )}$ & $\mathbf{( 9 )}$ & $\mathbf{( 1 0 )}$ \\
\hline (1) CNV & $\mathbf{0 . 9 3}$ & & & & & & & & & \\
\hline (2) IA & 0.77 & $\mathbf{0 . 9 0}$ & & & & & & & & \\
\hline (3) PS & 0.83 & 0.83 & $\mathbf{0 . 9 4}$ & & & & & & & \\
\hline (4) PR & 0.32 & 0.39 & 0.39 & $\mathbf{0 . 8 7}$ & & & & & & \\
\hline (5) TD & 0.77 & 0.86 & 0.82 & 0.47 & $\mathbf{0 . 9 0}$ & & & & & \\
\hline (6) SC & 0.54 & 0.69 & 0.60 & 0.54 & 0.76 & $\mathbf{0 . 8 5}$ & & & & \\
\hline (7) ADV & 0.50 & 0.43 & 0.52 & 0.55 & 0.55 & 0.49 & $\mathbf{0 . 8 9}$ & & & \\
\hline (8) AUT & 0.64 & 0.63 & 0.65 & 0.48 & 0.69 & 0.58 & 0.67 & $\mathbf{0 . 9 2}$ & & \\
\hline (9) PI & 0.62 & 0.60 & 0.64 & 0.49 & 0.66 & 0.57 & 0.68 & 0.71 & $\mathbf{0 . 8 5}$ & \\
\hline (10) WOMI & 0.42 & 0.42 & 0.42 & 0.53 & 0.51 & 0.57 & 0.51 & 0.51 & 0.59 & $\mathbf{0 . 8 4}$ \\
\hline & & & & & & & & & & \\
\hline Mean & 4.69 & 4.84 & 4.34 & 3.10 & 4.27 & 4.05 & 2.67 & 3.54 & 3.13 & 3.07 \\
\hline Standard Deviation & 2.00 & 1.80 & 1.84 & 1.91 & 1.81 & 1.96 & 1.74 & 1.81 & 1.97 & 2.01 \\
\hline Cronbach Alpha & 0.93 & 0.88 & 0.93 & 0.85 & 0.88 & 0.80 & 0.87 & 0.90 & 0.90 & 0.89 \\
\hline AVE & 0.87 & 0.81 & 0.88 & 0.76 & 0.81 & 0.72 & 0.80 & 0.84 & 0.73 & 0.71 \\
\hline
\end{tabular}

\section{$5 \quad$ Analysis}

\subsection{Methodology and Calibration}

To determine user profiles and the combinations of aspects on social media that enhance their intentions to purchase and word-of-mouth this study employs a fuzzy-set Qualitative Comparative Analysis (fsQCA). FsQCA adheres to the principles of configuration theory which in essence allows for the examination of interplays that develop between elements of a messy and non-linear nature [45]. The main difference of fsQCA with other statistical methods is that it supports equafinality, meaning that a particular outcome (e.g. high purchase intention) may be caused by different combination of elements. This is particularly relevant to the context of online shopping since consumers differ in the aspects that trigger their behaviour. As such, it is important to isolate what combination of affordances present on social media motivate specific consumer groups to purchase and share information. FsQCA follows such a paradigm since it is geared towards reducing elements for each patterns to the fundamentally necessary and sufficient conditions. In addition, fsQCA further supports the occurrence of causal asym- 
metry. Causal asymmetry means that, for an outcome to occur, the presence and absence of a causal condition depend on how this causal condition combines with one or more other causal conditions [46].

The first step in conducting an fsQCA analysis is calibrating dependent and independent variables into fuzzy or crisp sets. The fuzzy of fuzzy sets may range anywhere on the continuous scale from 0 , which denotes an absence of set membership, to 1 , which indicates full set membership. Crisp sets are more appropriate in categorical variables that have two, and only two options. The procedure followed of transforming continuous variables into fuzzy sets is grounded on the method proposed by Ragin [47]. According to the procedure, the degree of set membership is based on three anchor values. These represent a full set membership threshold value (fuzzy score $=0.95$ ), a full non-membership value (fuzzy score $=0.05$ ), and the crossover point (fuzzy score $=0.50$ ) [48]. Since this study uses a 7-point likert scale to measure constructs, the guidelines put forth by Ordanini et al. [49] are followed to calibrate them into fuzzy sets. Therefore, full membership thresholds are set for values over 5.5, the cross over point is set at 4, and full non-membership values at 2.5. The gender of respondents is coded as 1 for males and 0 for females, while low spenders (marked with a value of 0 ) are those that spend up to $24 € /$ month and high spenders (marked with a value of 1 ) those that spend over $25 € /$ month based on median split.

\subsection{Fuzzy set qualitative comparative analysis}

By performing two separate fsQCA analyses truth tables of $2^{\mathrm{k}}$ rows each are produced, where $\mathrm{k}$ represents the number of predictor elements, and each row indicates a possible combination (solution). Solutions that have a consistency level lower than 0.75 are disregarded [50]. Consistency is a measure of the degree to which a subset relation has been approximated. In addition, a minimum of two cases for each solution is set [50]. Having established these parameters, the fsQCA analyses are then performed using high purchase and word-of-mouth intention as the dependent variables. The outcomes of the fuzzy set analysis are presented in Table 4. The solutions are presented in the columns with the black circles denoting the presence of a condition, the crossed-out circles indicating an absence of it, while the blank spaces represent a "don't care" situation in which the causal condition may be either present or absent [50].

Table 4. Configurations for high purchase and word-of-mouth intentions

\begin{tabular}{|c|c|c|c|c|c|c|c|c|}
\hline \multirow{3}{*}{ Configuration } & \multicolumn{8}{|c|}{ Solution } \\
\hline & \multicolumn{4}{|c|}{ Purchase Intentions } & \multicolumn{4}{|c|}{$\begin{array}{l}\text { Word-of-Mouth } \\
\text { Intentions }\end{array}$} \\
\hline & 1 & 2 & 3 & 4 & 1 & 2 & 3 & 4 \\
\hline \multicolumn{9}{|l|}{ Demographics } \\
\hline Gender & O & O & $\otimes$ & $\otimes$ & O & $\otimes$ & $\otimes$ & $\otimes$ \\
\hline High Spending & 0 & $\otimes$ & 0 & 0 & & 0 & 0 & $\otimes$ \\
\hline \multicolumn{9}{|l|}{ Utilitarian Motivations } \\
\hline Convenience & 0 & 0 & & & & 0 & & \\
\hline
\end{tabular}




\begin{tabular}{|l|}
\hline Information Availability \\
\hline Product Selection \\
\hline Personal Recommendations \\
\hline \\
\hline Hedonic Motivation \\
\hline Trend Discovery \\
\hline Socializing \\
\hline Adventure \\
\hline Authority and Status \\
\hline
\end{tabular}

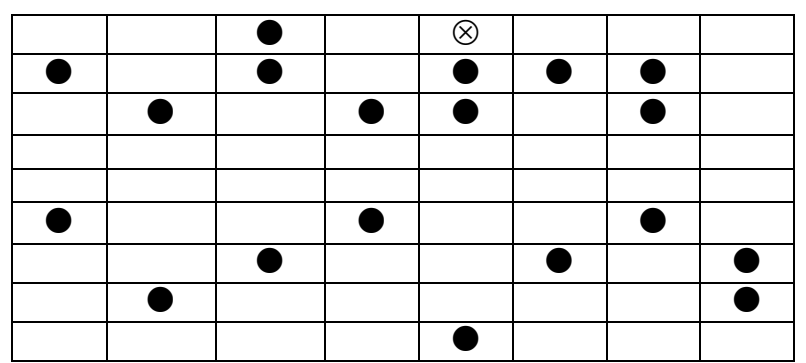

\begin{tabular}{|c|c|c|c|c|c|c|c|c|}
\hline Consistency & 0.822 & 0.864 & 0.935 & 0.752 & 0.902 & 0.781 & 0.741 & 0.793 \\
\hline Raw Coverage & 0.335 & 0.182 & 0.132 & 0.069 & 0.235 & 0.203 & 0.099 & 0.096 \\
\hline Unique Coverage & 0.215 & 0.062 & 0.012 & 0.021 & 0.183 & 0.126 & 0.027 & 0.038 \\
\hline Overall Solution Consistency & \multicolumn{4}{|c|}{0.785} & \multicolumn{4}{|c|}{0.805} \\
\hline Overall Solution Coverage & \multicolumn{4}{|c|}{0.432} & \multicolumn{4}{|c|}{0.416} \\
\hline
\end{tabular}

The outcomes of the analysis for high purchase intentions yield four different solutions. The first two concern male consumers while the latter two female ones. Specifically, solution 1 proposes that males that are flagged as high spenders are propelled to purchase on social media due to convenience, the product selection, and well as the ability to discover new trends on social media. Solution 2 differs in that it addresses low spending consumers whom are found to be influenced by the convenience of social media, personal recommendations presented to them, as well as the sense of adventure perceived while browsing products. Solutions 3 and 4 are oriented towards females with high spending habits. The former of these two solutions places emphasis on information availability, the product selection, and the ability to socialize on social media, while the later on personal recommendations and the capacity to discover new trends.

The analysis for high word-of-mouth intentions results in four different solutions, in which one is directed towards males and the other three towards females. Solutions 1 indicated that males are highly likely to engage in word-of-mouth when there is a lack of information, there is a large product selection, personal recommendations are present, and they are able to discover trends. Solutions 2 and 3 explain high word-of-mouth intentions for females that have a high spending profile. These type of consumers are influenced either by the convenience of social media combined with a broad product selection and an ability to socialize, or by a wide product selection, personal recommendation affordances, and the ability to discover new trends. Finally, solution 4 concerns females with low spending behaviour. This profile of user is propelled to engage in word-of-mouth primarily based on hedonic motivations sparked by social media, such as socializing and feeling a sense of adventure.

\section{Discussion}

The present paper suggests that consumer intentions to purchase and engage in wordof-mouth on social are propelled by a combination of different factors present on such 
mediums. To examine what aspects facilitate consumer intentions to purchase and word-of-mouth, a conceptual model is proposed which distinguishes between utilitarian and hedonic aspects of social media platforms. While utilitarian and hedonic motivations have been extensively examined in research studies relating to shopping, at both physical and electronic shops, limited studies have examined their impact on social media platforms to date. Building on this gap, the present study has explored how these two types of motivations influence consumer intentions to purchase and word-ofmouth. Taking also into account personal characteristics such as gender and money spent, outcomes of the fsQCA analyses indicate that multiple solutions exist in influencing consumer intents. The results highlight the importance of focusing on specific combinations of aspects to enhance consumer engagement.

More specifically, our outcomes demonstrate that all the examined aspects of social media can trigger consumer intentions, but not all are effective in the same settings. The gender of consumers and spending habits do in fact regulate the affordances that are responsible for initiating purchase and word-of-mouth intentions. These outcomes demonstrate that not all consumers operate in the same way on social media, thus, requirements in terms of functionality and content may differ. This poses an interesting practical implication for companies that want to formulate commerce strategies over social media. Depending on the profile of consumers that are targeted, attention can be given to different aspects of the medium such as the diversity of products and the accompanying information, attributes that enhance adventure such as gamification techniques and rewards, socializing initiatives, or customization features based on consumer information [51]. Literature has recognized two primary types of social commerce initiatives; e-commerce website that utilize social media tools and concepts (e.g. Amazon), and those that are built on social media platforms that add e-commerce affordances (e.g. Facebook) [52]. As such, the combination of utilitarian and hedonic aspects can be accentuated in either of these two settings.

From a theoretical point of view this study confirms that it does not make sense to categorize consumers as solely utilitarian or hedonic, since during the purchasing process both types of motivations influence their intentions. In addition, considering utilitarian and hedonic aspects of social media platforms as a whole does not provide any guidance, but what is more beneficial is to distinguish factors pertinent to each category. The use of the fsQCA methodology also demonstrates that there is no aspect that is superior than the other in terms of initiating consumer behaviour, but rather, that each is valuable when coupled with others. In addition, our findings confirm the suggestion of past studies that gender differences exist in terms of shopping and motivations. We find that this is also applicable in the social commerce context for both purchasing and word-of-mouth intentions. The same applies for the money they tend to spend online, with the patterns of elements influencing low spenders being different than those of high spenders. Ultimately, these findings showcase that there is no universally optimal way of deploying social commerce strategies for companies. What is necessary is that a careful customer segmentation is performed and the main target groups are located correctly. Since social media provide a rich background of information of consumers, 
it is highly probable that in the future social commerce interfaces will be highly personalized, not only with respect to content, but also in terms of structure and functionality $[53,54]$.

\section{Conclusions}

While results of this study have shed some light on the utilitarian and hedonic aspects of social media that promote consumers' intentions to purchase and word-of-mouth, they must be considered under their limitations. First, the distinction of consumers based on gender and purchasing expenditure can be expanded to further refine their profiles. Elements such as product type, price, availability, computer literacy, trust, and age can also result in different aspects that are found as important. Second, the robustness of results could be increased by utilizing a larger sample size. Third, although the intention to word-of-mouth is examined as an outcome of motivations, the scope and audience to which it will be addressed is not controlled for. Based on the abovementioned limitations, future studies could direct efforts towards better understanding the actions taken by consumers and how the design and content of social media influences these decisions. Towards this direction, the use of fsQCA could provide a useful tool in thinking of non-linear and synergistic effects on desired outcomes [55].

\section{Acknowledgments}

This project has received funding from the European Union's Horizon 2020 research and innovation programme under the Marie Sklodowska-Curie grant agreement No 704110 .

This work was carried out during the tenure of an ERCIM "Alain Bensoussan" Fellowship Programme.

\section{References}

1. Mangold, W. G., Faulds, D. J.: Social media: The new hybrid element of the promotion mix. Business Horizons. 52, 357-365 (2009)

2. Berthon, P. R., Pitt, L. F., Plangger, K., Shapiro, D.: Marketing meets Web 2.0, social media, and creative consumers: Implications for international marketing strategy. Business horizons. 55, 261-271 (2012).

3. Kim, Y., Srivastava, J.: Impact of social influence in e-commerce decision making. In: Proceedings of the ninth international conference on Electronic commerce, pp. 293-302 (2007).

4. Parise, S., Guinan, P. J.: Marketing using web 2.0. In: Hawaii International Conference on System Sciences, Proceedings of the 41st Annual, pp. 281-281. IEEE (2008).

5. Liang, T. P., Turban, E.: Introduction to the special issue social commerce: a research framework for social commerce. International Journal of Electronic Commerce. 16, 5-14 (2011).

6. Fournier, S., Avery, J.: The uninvited brand. Business Horizons. 54, 193-207 (2011). 
7. Wang, C., Zhang, P.: The evolution of social commerce: The people, management, technology, and information dimensions. Communications of the Association for Information Systems. 31, 1-23 (2012).

8. Childers, T. L., Carr, C. L., Peck, J., Carson, S.: Hedonic and utilitarian motivations for online retail shopping behavior. Journal of retailing. 77, 511-535 (2002).

9. Tauber, E. M.: Why do people shop?. The Journal of Marketing. 36, 46-49 (1972).

10. Babin, B. J., Lee, Y. K., Kim, E. J., Griffin, M.: Modeling consumer satisfaction and wordof-mouth: restaurant patronage in Korea. Journal of Services Marketing. 19, 133-139 (2005).

11. Jones, M. A., Reynolds, K. E., Arnold, M. J.: Hedonic and utilitarian shopping value: Investigating differential effects on retail outcomes. Journal of Business Research. 59, 974-981 (2006).

12. Mikalef, P., Giannakos, M., Pateli, A.: Shopping and word-of-mouth intentions on social media. Journal of theoretical and applied electronic commerce research. 8, 17-34 (2013).

13. Batra, R., Ahtola, O. T.: Measuring the hedonic and utilitarian sources of consumer attitudes. Marketing Letters. 2, 159-170 (1991).

14. O'Brien, H. L.: The influence of hedonic and utilitarian motivations on user engagement: The case of online shopping experiences. Interacting with Computers. 22, 344-352 (2010).

15. Pappas, I. O., Kourouthanassis, P. E., Giannakos, M. N., Chrissikopoulos, V.: Explaining online shopping behavior with fsQCA: The role of cognitive and affective perceptions. Journal of Business Research. 69, 794-803 (2016).

16. Mikalef, P., Giannakos, M., Pateli, A. Exploring the business potential of social media: An utilitarian and hedonic motivation approach. In: Proceedings of the 25 th Bled eConference eDependability: Reliable and Trustworthy eStructures, eProcesses, eOperations and eServices for the Future Proceedings, Bled, Slovenia, pp. 1-14 (2012).

17. Chitturi, R., Raghunathan, R., Mahajan, V.: Delight by design: The role of hedonic versus utilitarian benefits. Journal of Marketing. 72, 48-63 (2008).

18. Cheung, C. M., Lee, M. K.: What drives consumers to spread electronic word of mouth in online consumer-opinion platforms. Decision Support Systems. 53, 218-225 (2012).

19. Mikalef, P., Pateli, A., Giannakos, M.: Why are users of Social Media inclined to Word-ofMouth?. In: Collaborative, Trusted and Privacy-Aware e/m-Services, pp. 112-123. Springer Berlin Heidelberg (2013).

20. Alba, J., Lynch, J., Weitz, B., Janiszewski, C., Lutz, R., Sawyer, A., Wood, S.: Interactive home shopping: consumer, retailer, and manufacturer incentives to participate in electronic marketplaces. The Journal of Marketing. 61, 38-53 (1997).

21. Morganosky, M. A., Cude, B. J.: Consumer response to online grocery shopping. International Journal of Retail \& Distribution Management. 28, 17-26 (2000).

22. Falk, P., Campbell, C.: The shopping experience. Sage, London (1997).

23. Eroglu, S. A., Machleit, K. A., Davis, L. M.: Atmospheric qualities of online retailing: A conceptual model and implications. Journal of Business research. 54, 177-184 (2001).

24. Mathwick, C., Malhotra, N., Rigdon, E.: Experiential value: conceptualization, measurement and application in the catalog and Internet shopping environment. Journal of retailing. 77, 39-56 (2001).

25. Kim, H. W., Gupta, S., Koh, J.: Investigating the intention to purchase digital items in social networking communities: A customer value perspective. Information \& Management. 48, 228-234 (2011).

26. He, W., Zha, S., Li, L.: Social media competitive analysis and text mining: A case study in the pizza industry. International Journal of Information Management. 33, 464-472 (2013).

27. Keeney, R. L.: The value of Internet commerce to the customer. Management Science. 45, 533-542 (1999). 
28. Wolfinbarger, M., Gilly, M. C.: Shopping online for freedom, control, and fun. California Management Review. 43, 34-55 (2001).

29. Arnold, M. J., Reynolds, K. E.: Hedonic shopping motivations. Journal of retailing. 79, 7795 (2003).

30. To, P. L., Liao, C., Lin, T. H.: Shopping motivations on Internet: A study based on utilitarian and hedonic value. Technovation. 27, 774-787 (2007).

31. Chung, C., Austria, K.: Social Media Gratification and Attitude toward Social Media Marketing Messages: A Study of the Effect of Social Media Marketing Messages on Online Shopping Value. In: Proceedings of the Northeast Business \& Economics Association (2010).

32. Brown, M., Pope, N., Voges, K.: Buying or browsing? An exploration of shopping orientations and online purchase intention. European Journal of Marketing. 37, 1666-1684 (2003).

33. Van Slyke, C., Comunale, C. L., Belanger, F.: Gender differences in perceptions of webbased shopping. Communications of the ACM. 45, 82-86 (2002).

34. Gefen, D., Straub, D. W.: Gender differences in the perception and use of e-mail: An extension to the technology acceptance model. MIS Quarterly. 21, 389-400 (1997).

35. Bellman, S., Lohse, G. L., Johnson, E. J.: Predictors of online buying behavior. Communications of the ACM. 42, 32-38 (1999).

36. Correa, T., Hinsley, A. W., De Zuniga, H. G.: Who interacts on the Web?: The intersection of users' personality and social media use. Computers in Human Behavior. 26, 247-253 (2010).

37. Burke, R. R.: Do you see what I see? The future of virtual shopping. Journal of the Academy of Marketing Science. 25, 352-360 (1997).

38. Chiang, K. P., Dholakia, R. R.: Factors driving consumer intention to shop online: an empirical investigation. Journal of Consumer psychology.13, 177-183 (2003).

39. Han, J., Han, D.: A framework for analyzing customer value of internet business. JITTA: Journal of Information Technology Theory and Application. 3, 25 (2001).

40. Westbrook, R. A., Black, W. C.: A motivation-based shopper typology. Retailing: Critical concepts. The Environments for Retailing. 2, 82 (2002).

41. Parsons, A. G.: Non-functional motives for online shoppers: why we click. Journal of Consumer Marketing. 19, 380-392 (2002).

42. Van der Heijden, H. User acceptance of hedonic information systems. MIS Quarterly. 28, 695-704 (2004).

43. Brown, J., Broderick, A. J., Lee, N.: Word of mouth communication within online communities: Conceptualizing the online social network. Journal of interactive marketing. 21, 2-20 (2007).

44. Hennig-Thurau, T., Gwinner, K. P., Walsh, G., \& Gremler, D. D. (2004). Electronic wordof-mouth via consumer-opinion platforms: What motivates consumers to articulate themselves on the Internet?. Journal of interactive marketing, 18(1), 38-52.

45. Fiss, P. C.: A set-theoretic approach to organizational configurations. Academy of management review. 32, 1180-1198 (2007).

46. Leischnig, A., Kasper-Brauer, K.: Employee adaptive behavior in service enactments. Journal of Business Research. 68, 273-280 (2015).

47. Ragin, C. C.: Redesigning social inquiry: Fuzzy sets and beyond. University of Chicago Press, Chicago (2008).

48. Woodside, A. G. Moving beyond multiple regression analysis to algorithms: Calling for adoption of a paradigm shift from symmetric to asymmetric thinking in data analysis and crafting theory. Journal of Business Research. 66, 463-472 (2013). 
49. Ordanini, A., Parasuraman, A., Rubera, G.: When the recipe is more important than the ingredients a Qualitative Comparative Analysis (QCA) of service innovation configurations. Journal of Service Research. 17, 134-149 (2013).

50. Ragin, C. C.: Set relations in social research: Evaluating their consistency and coverage. Political Analysis. 14, 291-310 (2006).

51. Zhang, H., Lu, Y., Gupta, S., Zhao, L.: What motivates customers to participate in social commerce? The impact of technological environments and virtual customer experiences. Information \& Management. 51, 1017-1030 (2014).

52. Huang, Z., Benyoucef, M.: From e-commerce to social commerce: A close look at design features. Electronic Commerce Research and Applications. 12, 246-259 (2013).

53. Yadav, M. S., De Valck, K., Hennig-Thurau, T., Hoffman, D. L., Spann, M.: Social commerce: a contingency framework for assessing marketing potential. Journal of Interactive Marketing. 27, 311-323 (2013).

54. Pappas, I.O., Kourouthanassis, P.E., Giannakos, M.N., Chrissikopoulos, V.: Shiny happy people buying: the role of emotions on personalized e-shopping. Electronic Markets, 24, 193-206 (2014).

55. Mikalef, P., Pateli, A., Batenburg, R.S., Wetering, R.v.d.: Purchasing alignment under multiple contingencies: a configuration theory approach. Industrial Management \& Data Systems, 115, 625-645 (2015).

\section{Appendix A. Questionnaire Items}

\begin{tabular}{|c|c|c|c|}
\hline Construct & Items & Mean & S.D \\
\hline \multicolumn{4}{|c|}{$\begin{array}{l}\text { For each of the following sentences please indicate how much you agree or disagree } \\
\text { with them ( } 1 \text { - totally disagree, } 7 \text { - totally agree })\end{array}$} \\
\hline [CNV_1] & $\begin{array}{l}\text { Social Media websites are a convenient medium since I can browse } \\
\text { products whenever I want to }\end{array}$ & 4.37 & 2.052 \\
\hline [CNV_2] & $\begin{array}{l}\text { It is convenient to browse products through Social Media since I can do } \\
\text { so in the comfort of my own space }\end{array}$ & 4.85 & 2.005 \\
\hline [CNV_3] & $\begin{array}{l}\text { Through Social Media I can browse products/services in accordance } \\
\text { with my schedule }\end{array}$ & 4.85 & 1.940 \\
\hline \multicolumn{4}{|c|}{ Information Availability } \\
\hline [IA_1] & $\begin{array}{l}\text { Social Media provide me with quick access to large volumes of infor- } \\
\text { mation about products/services }\end{array}$ & 4.90 & 1.792 \\
\hline [IA_2] & $\begin{array}{l}\text { Comments by other users of Social Media websites help in giving feed- } \\
\text { back about a product/service advertised }\end{array}$ & 4.89 & 1.796 \\
\hline [IA_3] & $\begin{array}{l}\text { I can collect useful information about a product/service I want through } \\
\text { Social Media websites }\end{array}$ & 4.79 & 1.773 \\
\hline \multicolumn{4}{|c|}{ Product Selection } \\
\hline [PS_1] & $\begin{array}{l}\text { Social Media help me find more products that I was unfamiliar with be- } \\
\text { fore }\end{array}$ & 4.47 & 1.832 \\
\hline [PS_2] & $\begin{array}{l}\text { I can find a wide selection of products in one website through Social } \\
\text { Media }\end{array}$ & 4.26 & 1.843 \\
\hline [PS_3] & With Social Media I can browse through a large array of products & 4.36 & 1.833 \\
\hline \multicolumn{4}{|c|}{ Personal Recommendations } \\
\hline [PR_1] & $\begin{array}{l}\text { I find that through information from my profile on Social Media web- } \\
\text { sites, I am presented with product advertisements that are more compat- } \\
\text { ible to my likings }\end{array}$ & 3.73 & 2.072 \\
\hline [PR_2] & $\begin{array}{l}\text { Products presented to me on Social Media platforms are customized to } \\
\text { my needs }\end{array}$ & 3.37 & 1.841 \\
\hline [PR_3] & $\begin{array}{l}\text { Product recommendations on Social Media websites make me feel as an } \\
\text { important customer }\end{array}$ & 2.23 & 1.640 \\
\hline
\end{tabular}


Trend Discovery

[TD_1] Social Media provide me with access to new trends $\quad 4.34 \quad 1.825$

[TD_2] Through social media I am able to keep up with new fashions $\quad 4.50 \quad 1.855$

[TD_3] I can see what new products are available on social media $\quad 4.26 \quad 1.780$

$\begin{array}{lllll}\text { Socializing } & \text { Social Media provide a great platform in order to exchange information } 4.39 & 1.715\end{array}$

$\begin{array}{llll} & \text { with my friends regarding products } \\ \text { [SC_2] } & \text { Through Social Media I can effectively share my experience of a newly } & 4.64 & 1.830\end{array}$

$\begin{array}{llll} & \text { purchased product or service with others } \\ \text { [SC_3] } & \text { I can engage in friendships with other shoppers through Social Media } & 3.15 & 1.988\end{array}$

Adventure

[ADV_1] I find browsing products through Social Media to be stimulating $\quad 2.86 \quad 1.726$

[ADV_2] To me, browsing products via Social Media websites is an adventure $\quad 2.49 \quad 1.691$

[ADV_3] I get drawn in to a world of my own when browsing products on Social $\quad 2.60 \quad 1.774$

Authority and Status

$\begin{array}{llll}\text { [AUT_1] } & \text { When browsing products on Social Media websites I feel I am in control } & 3.41 & 1.863\end{array}$

[AUT_2] Through Social Media websites I feel that I have a good understanding $\quad 3.70 \quad 1.818$

$\begin{array}{llll} & \text { on the product features which I am browsing } & 3.60 & 1.777\end{array}$

Purchase Intention

[PI_1] I purchase some of the products or services which I have browsed $3.40 \quad 1.995$

[PI_2] After some time of thought I buy one or more products which I have $\quad 3.17 \quad 1.970$

[PI_3] Some of my recent purchases were based on information which I found $\quad 3.42 \quad 2.197$

$\begin{array}{llll} & \text { via Social Media sites } \\ \text { [PI_4] I buy products I see advertised on Social Media through e-shops } & 2.85 & 1.893\end{array}$

[PI_5] I buy products I see advertised on Social Media through shops nearby $3.01 \quad 1.856$ me

Word-of-Mouth Intentions

[WOMI_1] I sometimes share with my friends through Social Media, products, $3.75 \quad 1.958$ brands or services that I like

[WOMI_2] I send invitations to my friends to join a group of a product/brand on a $\quad 2.37 \quad 1.792$ Social Media site

[WOMI_3] When I see a product I like on a Social Media website I use a "Like" or $\quad 3.09 \quad 2.112$ " +1 " function to show my appreciation

[WOMI_4] I would say positive things through a Social Media website about prod- $\quad 3.72 \quad 2.001$ ucts I like

[WOMI_5] I send invitations to friends so that they can join groups of brands and $\quad 2.54 \quad 1.918$ products which I believe they would like 